\title{
Neutral pH
}

National Cancer Institute

\section{Source}

National Cancer Institute. Neutral pH. NCI Thesaurus. Code C63342.

Neither chemically acidic or basic. 